\title{
Retardation of Cochlear Maturation and Impaired Hair Cell Function Caused by Deletion of All Known Thyroid Hormone Receptors
}

\author{
Alfons Rüsch, ${ }^{1}$ Lily Ng, ${ }^{2}$ Richard Goodyear, ${ }^{3}$ Dominik Oliver, ${ }^{1}$ Igor Lisoukov, ${ }^{2}$ Björn Vennström, ${ }^{4}$ \\ Guy Richardson, ${ }^{3}$ Matthew W. Kelley, ${ }^{5}$ and Douglas Forrest ${ }^{2}$
}

${ }_{1}^{1}$ Physiologisches Institut and Sektion Sensorische Biophysik, Hals-Nasen-Ohren Klinik, Röntgenweg 11, Universität Tübingen, D-72076 Tübingen, Germany, 2Department of Human Genetics, Mount Sinai School of Medicine, New York, New York 10029, ${ }^{3}$ School of Biological Sciences, The University of Sussex, Falmer, Brighton, BN19QG, United Kingdom, ${ }^{4}$ Department of Cell and Molecular Biology, Karolinska Institute, S-17 177, Stockholm, Sweden, and 5National Institute of Deafness and Communication Disorders, National Institutes of Health, Rockville, Maryland 20850

The deafness caused by early onset hypothyroidism indicates that thyroid hormone is essential for the development of hearing. We investigated the underlying roles of the $\operatorname{TR} \alpha 1$ and $\operatorname{TR} \beta$ thyroid hormone receptors in the auditory system using receptor-deficient mice. TR $\alpha 1$ and $\operatorname{TR} \beta$, which act as hormoneactivated transcription factors, are encoded by the Thra and Thrb genes, respectively, and both are expressed in the developing cochlea. $\operatorname{TR} \beta$ is required for hearing because $\operatorname{TR} \beta$ deficient $\left(T h r b^{t m 1 / t m 1}\right)$ mice have a defective auditory-evoked brainstem response and retarded expression of a potassium current $\left(I_{K, f}\right)$ in the cochlear inner hair cells. Here, we show that although TR $\alpha 1$ is individually dispensable, $\operatorname{TR} \alpha 1$ and $\operatorname{TR} \beta$ synergistically control an extended array of functions in postnatal cochlear development. Compared with $T h r b^{\operatorname{tm} 1 / \mathrm{tm} 1}$ mice, the deletion of all TRs in Thra ${ }^{\mathrm{tm} 1 / \mathrm{tm} 1} \mathrm{Thrb}^{\mathrm{tm} 1 / \mathrm{tm} 1}$ mice produces exacerbated and novel phenotypes, including delayed differentiation of the sensory epithelium, malformation of the tectorial membrane, impairment of electromechanical transduction in outer hair cells, and a low endocochlear potential. The induction of $I_{\mathrm{K}, \mathrm{f}}$ in inner hair cells was not markedly more retarded than in Thrb ${ }^{\text {tm1/tm1 }}$ mice, suggesting that this feature of hair cell maturation is primarily $\operatorname{TR} \beta$-dependent. These results indicate that distinct pathways mediated by $\operatorname{TR} \beta$ alone or by $\operatorname{TR} \beta$ and TR $\alpha 1$ together facilitate control over an extended range of functions during the maturation of the cochlea.

Key words: cochlea; development; tectorial membrane; hair cell; thyroid hormone receptor; transcription factor
Thyroid hormone is essential for the development of hearing. Deafness arises if there is insufficient hormone available during sensitive periods in the fetal and possibly early neonatal period in humans (Trotter, 1960; Morreale de Escobar et al., 1996) and in the neonatal period in rodents (Deol, 1973; Van Middlesworth and Norris, 1980; Uziel, 1986). Despite the well known requirement for thyroid hormone, however, relatively little is known of the receptor pathways underlying the actions of this hormone in the auditory system.

The TR $\alpha 1$ and $\operatorname{TR} \beta$ thyroid hormone receptors, encoded by the related Thra and Thrb genes, respectively, act as hormoneactivated transcription factors (Sap et al., 1986; Weinberger et al., 1986), and both are expressed in the developing cochlea. The Thrb gene is expressed in the organ of Corti, which contains the sensory hair cells, where it is prominently expressed in the greater

\footnotetext{
Received July 12, 2001; revised Sept. 18, 2001; accepted Oct. 3, 2001.

This work was supported in part by the German Research Council (Deutsche Forschungsgemeinschaft; A.R.), the Swedish Cancer Fund (B.V.), the Wellcome Trust (Grant 057410/Z/99/Z; R.G. and G.R.), and March of Dimes, the Deafness Research Foundation, National Institutes of Health Grant DC 03441, and a Hirschl Award (D. F.).We thank Prof. J. P. Ruppersberg and Prof. B. Fakler (Department of Physiology, University of Tübingen, Tübingen, Germany) and Prof. H. P. Zenner (Ear, Nose, and Throat Hospital, University of Tübingen, Tübingen, Germany) for providing lab space and equipment and Dr. Christine Petit for otogelin antibody.

A.R. and L.N. contributed equally to this work.

Correspondence should be addressed to Douglas Forrest, Department of Human Genetics, Mount Sinai School of Medicine, Box 1498, 1425 Madison Avenue, New York, NY 10029. E-mail: douglas.forrest@mssm.edu.

Copyright (ㄷ) 2001 Society for Neuroscience 0270-6474/01/219792-09\$15.00/0
}

epithelial ridge. Thra is more widely expressed throughout the cochlea (Bradley et al., 1994; Lauterman and ten Cate, 1997; Knipper et al., 1998). The expression patterns of $\operatorname{TR} \alpha 1$ and $\operatorname{TR} \beta$ suggest that the cochlea is a direct site of action of thyroid hormone, consistent with findings of morphological abnormalities in the organ of Corti in hypothyroid rodents (Deol, 1973, 1976; Uziel et al., 1981; O’Malley et al., 1995). Hypothyroidism retards the development of the greater epithelial ridge and malforms the tectorial membrane (TM), which normally contacts the stereociliary bundles of the mechanosensitive hair cells. An intact TM is necessary for the response of the hair cell to acoustic stimulation and for the tuning of basilar membrane motion mediated by the electromotility of the outer hair cells (Dallos et al., 1996; Legan et al., 2000; Steel and Kros, 2001). Although thyroid hormone is known to be required for the morphological differentiation of the organ of Corti, less is known of the role of this hormone in the development of the physiological functions of the cochlea.

We showed previously that TR $\beta$-deficient $\left(T h r b^{t m 1 / t m 1}\right)$ but not TR $\alpha 1$-deficient (Thra ${ }^{\text {tml/tml }}$ ) mice have impaired auditoryevoked brainstem responses (Forrest et al., 1996; Rüsch et al., 1998). The deletion of $\operatorname{TR} \beta$ also results in deafness in a human kindred with recessive resistance to thyroid hormone (Refetoff et al., 1967), and mild hearing loss has been reported in $20 \%$ of the dominant cases of this syndrome that are associated with $\operatorname{TR} \beta$ point mutations (Brucker-Davis et al., 1996). Thrb ${ }^{t m 1 / t m 1}$ mice have developmentally retarded expression of a potassium current, $I_{\mathrm{K}, \mathrm{f}}$, in their inner hair cells (Rüsch et al., 1998). $I_{\mathrm{K}, \mathrm{f}}$ normally 


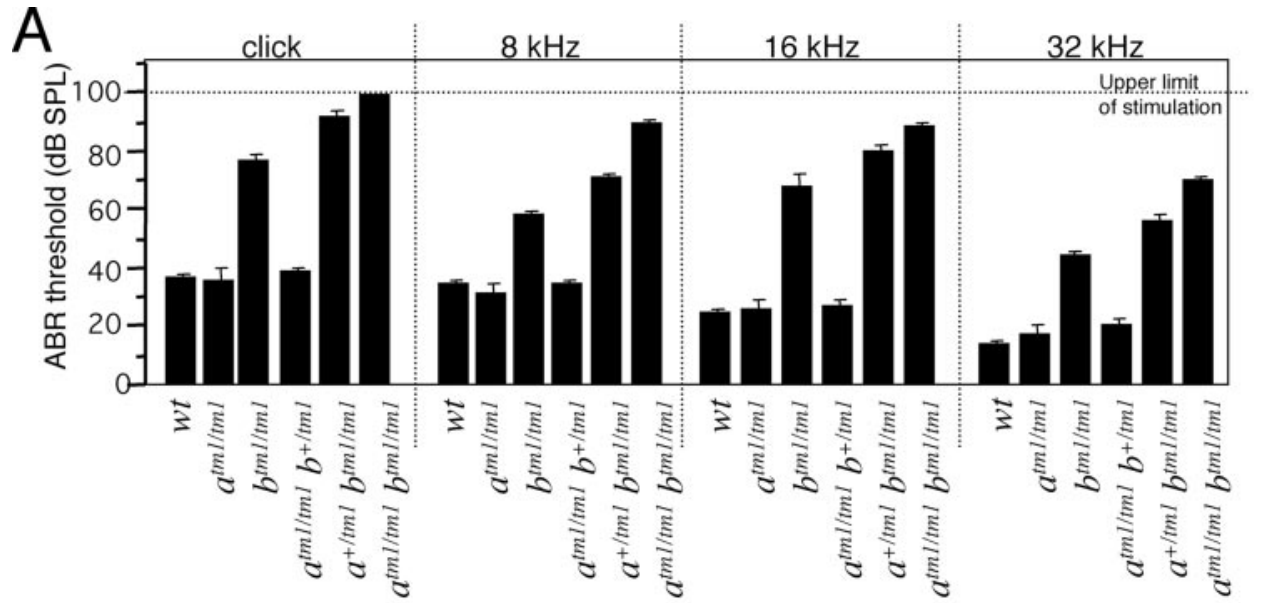

B

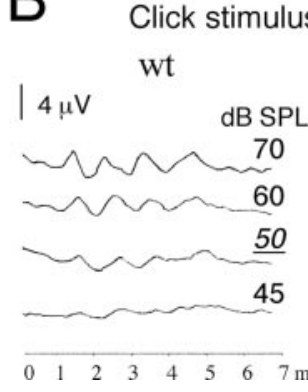

Click stimulus
Thra ${ }^{t m l / t m l}$
C

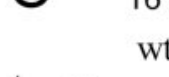

$16 \mathrm{kHz}$ stimulus

wt

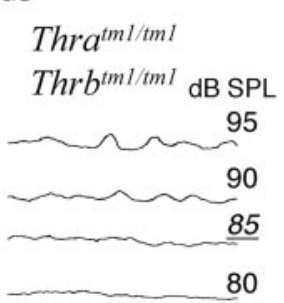

Figure 1. ABR thresholds in mice with single or combined deletions of TR $\alpha 1$ and TR $\beta . A$, Mean ABR thresholds \pm SEM (in decibels of SPL) for wild-type (wt), Thra $^{\text {tml/tm1 }}\left(a^{\text {tm1/tml }}\right)$, Thrb $^{\text {tm1/tm1 }}\left(b^{\text {tm1/tm1 }}\right)$, Thra $^{\text {tml/tml }}$ Thrb $^{\text {tml/tml }}\left(a^{\text {tml/tml }} b^{\text {tml/tml }}\right)$ mice, or other combined mutant strains. All genotypes were on a uniform, congenic C57BL/6J $(N>10)$ background. Responses to click, 8,16 , and $32 \mathrm{kHz}$ stimuli are shown. Groups shown contained $n=7-8$ mice at $5-13$ weeks of age. Thresholds were undetectable or were significantly elevated $(p<$ 0.01) in Thra $^{\text {tm1/tm1 }} \mathrm{Thrb}^{\mathrm{tml} / \mathrm{tml}}$ mice compared with wt or $T h r b^{t m 1 / t m 1}$ mice for all stimulus frequencies tested. $B, C$, Representative ABR waveforms for wt and $\mathrm{Thra}^{\text {tml/tml }} \mathrm{Thrb}^{\mathrm{tml} / \mathrm{tml} 1}$ mice in response to click $(B)$ and $16 \mathrm{kHz}(C)$ stimuli. Waveforms are shown on a $4 \mu \mathrm{V}$ fixed scale for comparison (actual thresholds were determined on a normalized scale for sensitivity; see Materials and Methods). Thresholds are underlined. No waveform was detectable for $\operatorname{Thra}^{t m 1 / t m 1} T h r b^{t m 1 / t m 1}$ mice for the click stimulus. Only weak, atypical waveforms were detected for the $16 \mathrm{kHz}$ stimulus shown.

becomes active with the onset of auditory function at approximately postnatal day 13 (P13) and is thought to transform the immature hair cell into a high-frequency signal transmitter (Kros et al., 1998). Thrb $b^{\text {tm1/tm1 }}$ adult mice however, do not display major hypothyroid-like cochlear malformations (Forrest et al., 1996). Therefore, to investigate interactions between Thra and Thrb in cochlear development, we generated $T h r a^{t m 1 / t m 1} T_{h r b^{t m 1 / t m 1}}$ mice that lack all known TRs (Göthe et al., 1999). The results reveal that $\operatorname{TR} \alpha 1$ and $\operatorname{TR} \beta$ together facilitate control over an extended and novel array of functions in cochlear maturation.

\section{MATERIALS AND METHODS}

Mouse strains. The Thrb ${ }^{\text {tmlDf }}$ targeted mutation deletes all known Thrb products (Forrest et al., 1996). The Thra ${ }^{\text {tmlVen }}$ mutation specifically deletes the TR $\alpha 1$ receptor product of Thra while leaving intact the TR $\alpha 2$ nonreceptor splice variant product of this gene (Wikström et al., 1998). Some histology and physiological studies were performed on mutant mice with a mixed background of equal parts $129 / \mathrm{Sv}, \mathrm{C} 57 \mathrm{BL} / 6 \mathrm{~J}$, $129 \mathrm{OlaHsd}$, and BALB/c strains. To remove background variability for auditory-evoked brainstem response (ABR) measurements, $T h r b^{t m I}$ and Thra $^{\text {tm } 1}$ mutations were separately backcrossed for 12 and 9 generations, respectively, to create congenic $\mathrm{C} 57 \mathrm{BL} / 6 \mathrm{~J}$ strains. These strains were

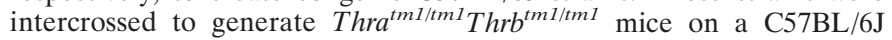
background; wild-type (wt) C57BL/6J mice do not show hearing loss until $>6$ months of age (Zheng et al., 1999). ABR results were similar on the mixed background except that variation was more marked. Thra $^{+/ t m l} \mathrm{Thrb}^{+/ t m 1}$ or $T h r a^{t m 1 / t m 1} \mathrm{Thrb}^{+/ t m 1}$ mice were interbred to generate $T h r a^{t m 1 / t m 1} T h r b^{t m 1 / t m 1}$ mice; double mutants themselves displayed infertility (Göthe et al., 1999). Genotypes were determined by PCR as described (Forrest et al., 1996; Wikström et al., 1998). Animal experiments followed all applicable guidelines and approved institutional protocols at Mount Sinai School of Medicine, the Karolinska Institute, and the University of Tübingen.

$A B R$. ABR tests were performed with a SmartEP ABR system, version 2.1, from Intelligent Hearing Systems (Miami, FL) essentially as described (Zheng et al., 1999). Mice were anesthetized with avertin $(0.25$ $\mathrm{mg} / \mathrm{gm}$ body weight) and active, reference, and ground electrode needles were placed subcutaneously at the vertex, ventrolateral to the left ear, and ventrolateral to the right ear, respectively. Binaural stimulation was presented with a rise-fall time of $1.5 \mathrm{msec}$, at a rate of $25 / \mathrm{sec}$. ABR thresholds were determined using decreasing intervals of $10 \mathrm{~dB}$ sound pressure level (SPL), which were reduced to $5 \mathrm{~dB}$ SPL determine the lowest threshold with visually recognizable ABR peaks on a normalized scale. Results were comparable with previous recordings with an older version of the apparatus from Intelligent Hearing Systems (Forrest et al., 1996). Slightly lower thresholds were detected at $32 \mathrm{kHz}$ in the present work, possibly because of the elimination of background strain variability or minor differences in the physical set up of the machines. Both machines were calibrated by the manufacturer. The ABR was analyzed on two series of mice on the congenic background. In addition to the results shown in Figure $1 A$, a second series of $n=52$ mice (males and females at ages of 5-12 weeks), including an additional $n=7 \mathrm{Thra}^{\mathrm{tml} / \mathrm{tml}} \mathrm{Thrb} \mathrm{tml/tml}^{\mathrm{tm}}$ mice, gave comparable results.

Whole-cell recording. The recording technique has been reported previously (Kros et al., 1998; Rüsch et al., 1998). Briefly, hair cells were studied after acute dissection of the most apical half-turn of the organ of Corti from mice at different postnatal ages. The isolated piece of the organ of Corti was mounted in a chamber and perfused at $10 \mathrm{ml} / \mathrm{hr}$ with an extracellular solution composed of (in mM): $144 \mathrm{NaCl}, 0.7 \mathrm{NaH}_{2} \mathrm{PO}_{4}$, $5.8 \mathrm{KCl}, 1.3 \mathrm{CaCl}_{2}, 0.9 \mathrm{MgCl}_{2}, 5.6 \mathrm{D}$-glucose, and 10 HEPES-NaOH, pH 7.3. Vitamins and amino acids for Eagle's minimal essential medium were added from concentrate (Life Technologies).

Membrane currents and voltages were studied at room temperature $\left(20-25^{\circ} \mathrm{C}\right)$ by whole-cell patch-clamp using an Axopatch $200 \mathrm{~B}$ amplifier. Patch pipettes were filled with an intracellular solution proven to sustain $\mathrm{Ca}^{2+}$ currents in hair cells (Platzer et al., 2000) (in $\mathrm{mM}$ ): $135 \mathrm{KCl}, 0.1$ $\mathrm{CaCl}_{2}, 3.5 \mathrm{MgCl}_{2}, 5 \mathrm{~K}_{2}$ EGTA, $2.5 \mathrm{Na}_{2} \mathrm{ATP}$, and 5 HEPES-KOH, pH 7.3. Currents under voltage clamp are presented with capacitive transient and linear leak currents subtracted; all voltages were corrected for the voltage drop across the uncompensated series resistance. Voltages were also corrected for the liquid junction potential between the intracellular and extracellular solutions $(-4 \mathrm{mV}$; as calculated by computer software by Peter Barry, University of New South Wales, Australia). Fifteen inner hair cells (IHCs) of the most apical half-turn of the cochlea from Thra ${ }^{t m 1 / t m 1} \mathrm{Thrb}^{\mathrm{tml/tml}}$ mice had a mean resting membrane potential of $-69 \pm 7 \mathrm{mV}$, which was similar to the mean $-70 \pm 8 \mathrm{mV}$ measured in $12 \mathrm{Thra}^{\mathrm{tml} / \mathrm{tml} 1} \mathrm{Thrb}^{+/ t m 1}$ and Thra $^{\mathrm{tml} / \mathrm{tml} 1}$ mice. The IHC fast current $I_{\mathrm{K}, \mathrm{f}}$ was measured at $-25 \mathrm{mV}$ between 2.4 and $3.6 \mathrm{msec}$ after the onset of the 
depolarizing voltage step, as shown in Figure $4 A$. The fits of the developmental expression pattern are according to a sigmoidal logistic growth curve:

$$
I=\left(I_{\max }-I_{\min }\right) /\left(1+\exp \left(-s\left(t-t_{1 / 2}\right)\right)+I_{\min }\right.
$$

where $I$ is current (in nanoamperes), $s$ is a slope factor $\left(d^{-1}\right), t$ is time (measured in days), and $t_{1 / 2}$ is the time at which $I$ is halfway between $I_{\max }$ and $I_{\min }$.

Capacitance. Motility-related nonlinear capacitance was measured as described previously (Oliver and Fakler, 1999). Briefly, outer hair cells (OHCs) were whole-cell voltage clamped, and their membrane capacitance was monitored using a software lock-in technique while the voltage was ramped from -120 to $+50 \mathrm{mV}$. Capacitance was plotted as a function of membrane potential and fitted with the derivative of a Boltzmann function (Santos-Sacchi, 1991). Values of nonlinear capacitance are given relative to the linear membrane capacitance of the cell (in femtofarads per picofarad) as determined from current transients induced by $10 \mathrm{mV}$ voltage steps.

Endocochlear potentials. Procedures followed described methods (Steel and Barkway, 1989; Rüsch et al., 1998). Mice were anesthetized with $20 \%$ urethane at $0.01 \mathrm{ml} / \mathrm{g}$ body weight. For $T h \mathrm{ra}^{\mathrm{tm} 1 / \mathrm{tm} 1} \mathrm{Thrb}^{\mathrm{tml} / \mathrm{tm} 1}$ mice, the surgical procedure had to be modified because of their 15 -fold enlarged thyroid gland (Göthe et al., 1999). A tracheotomy was not performed, and the head was held at the dorsal skull using dental cement. The cochlea was exposed as described previously (Rüsch et al., 1998). Potential measurements used a custom-made amplifier as a high impedance voltmeter. Statistical tests were two-tailed Student's $t$ tests.

Histology, cell counts, and electron microscopy. Mice were killed with $\mathrm{CO}_{2}$, then the temporal bones were isolated rapidly and fixed in $3 \%$ glutaraldehyde $/ 2 \%$ paraformaldehyde in PBS by overnight immersion. Thra ${ }^{t m 1 / t m 1}$ Thrb $^{\text {tml } 1 t m 1}$ cochlear samples were decalcified in $0.2 \mathrm{M}$ EDTA in PBS for 7-21 d, then embedded in methacrylate (Immunobed; Polysciences, Warrington, PA) and sectioned at 3-5 $\mu \mathrm{m}$ on a rotary microtome for histology; sections were stained with thionin. Cochleas from $n \geq 3$ mice per genotype at a given age were studied. Other cochleas were embedded in OCT glue and cryosectioned at 7-10 $\mu \mathrm{m}$ for immunostaining. Antibodies against $\alpha$ - and $\beta$-tectorins were used at 1:1000 dilution, and specific fluorescent staining was detected using FITC-conjugated secondary antibodies. Staining against otogelin was performed as described (Legan et al., 2000).

For cell counts, after fixation, the bony labyrinth, scala vestibuli, and Reissner's membrane were dissected to expose the apical surface of the sensory epithelium. The sensory epithelium was cut into thirds and placed on glass slides as whole mounts. Total numbers of hair cells were counted for $\geq 3$ cochleas per genotype for P8 pups and for adults using differential interference contrast microscopy.

For transmission electron microscopy, cochleas were rapidly removed, placed in PBS, the oval and round windows were removed, and a small hole was made in the apex of the bony capsule. Fixative $(2.5 \%$ glutaraldehyde in $0.1 \mathrm{M}$ sodium cacodylate, $\mathrm{pH} 7.2$, containing $1 \%$ tannic acid) was gently perfused through the opened windows, and the apical hole and cochleas were then immersed in the same fixative for a further $2 \mathrm{hr}$. Tissue pieces were washed three times in $0.1 \mathrm{M}$ sodium cacodylate buffer, $\mathrm{pH} 7.2$, post-fixed in $1 \%$ osmium tetroxide in $0.1 \mathrm{~m}$ sodium cacodylate, $\mathrm{pH} 7.2$, washed with cacodylate buffer, and decalcified in $0.5 \mathrm{~m}$ EDTA for $10-14 \mathrm{~d}$ at $4^{\circ} \mathrm{C}$. After decalcification, tissues were dehydrated through a series of ascending concentrations of ethanol, equilibrated with propylene oxide, and imbedded in TAAB 812 resin (TAAB Laboratories Equipment Ltd., Reading, UK). Blocks were cured for $2 \mathrm{~d}$ at $60^{\circ} \mathrm{C}$. For light microscopy of $T h r b^{\text {tm } 1 / t m 1}$ mice, $1-\mu$ m-thick sections were cut with glass knives and stained with Toluidine blue.

Ultrathin sections were cut with a diamond knife, double stained with uranyl acetate and lead citrate, and viewed with a Hitachi 7100 electron microscope operating at $75 \mathrm{kV}$. Cochleas from a total of 101 to 7-month-old wild-type mice, seven 4- to 6-month-old Thra ${ }^{\text {tml/tml }}$ $T h r b^{t m 1 / t m l}$ mice, and six 1- to 4-month-old $T h r b^{t m 1 / t m l}$ mice were examined.

\section{RESULTS}

\section{Combined roles of TR $\beta$ and TR $\alpha 1$ in auditory function}

The auditory-evoked brainstem response, an overall measure of auditory function, is impaired in TR $\beta$-deficient $T h r b^{t m 1 / t m 1}$ mice but is normal in TR $\alpha 1$-deficient $\mathrm{Thra}^{\mathrm{tm1/tm1}}$ mice (Forrest et al.,
1996; Rüsch et al., 1998). To investigate interactions between the Thra and Thrb genes, we analyzed the ABR in Thra $a^{\text {tm1/tm1 }}$ $T h r b^{t m 1 / t m 1}$ mice lacking all known TRs (Fig. 1). Thra ${ }^{\text {tm1/tm1 }}$ Thrb ${ }^{\text {tm1/tm1 }}$ mice were $30 \%$ smaller than wt mice but were viable, and despite fertility problems, thrived reasonably well (Göthe et al., 1999), thus allowing study of auditory function. ABR thresholds were assessed on a uniform, congenic C57BL/6J background to preclude hearing loss because of background strain variations. Thra ${ }^{\text {tm1/tm1 }}$ Thrb $^{\text {tm1/tm1 }}$ mice (shown as $a^{\text {tm1/tm1 }} b^{\text {tm1/tm1 in }}$ Fig. 1A) had significantly exacerbated defects compared with $T h r b^{t m 1 / t m 1}$ mice (shown as $\left.b^{t m 1 / t m 1}\right)(p<0.01)$ for click and pure tone stimuli $(8,16,32 \mathrm{kHz})$ that span the sensitive hearing range of mice. Thra ${ }^{\text {tm1/tm1 }} \mathrm{Thrb}^{\mathrm{tm1/tm1}}$ mice lacked any detectable click response at the upper limit of stimulation of the testing apparatus (100 dB SPL) and showed only weak, atypical responses for high-frequency stimuli (16 and $32 \mathrm{kHz}$ ). The waveforms of the residual responses to high frequencies could only be evoked with much elevated stimulus intensities ( $85 \mathrm{~dB}$ SPL threshold for 16 $\mathrm{kHz}$ shown in Fig. $1 C$ ) and were abnormal because the initial peaks within the first $2-3 \mathrm{msec}$ of stimulation that are usually the most prominent in mice (Zheng et al., 1999) were absent or delayed. $T h r a^{+/ t m 1} T h r b^{t m 1 / t m 1}$ mice had intermediate thresholds between those of $T h r b^{t m 1 / t m 1}$ and $T h r a^{t m 1 / t m 1} T h r b^{t m 1 / t m 1}$ mice, indicating a dosage function for TR $\alpha 1$. Thra ${ }^{\text {tm1/tm1 }} \mathrm{Thrb}^{+/ t m 1}$ mice, however, had normal thresholds, indicating that a single $\mathrm{Thrb}^{+}$wild-type allele was sufficient to sustain auditory function. The results demonstrate major interactions between Thra and Thrb in the auditory system.

\section{Cochlear morphology in TR-deficient mice}

Morphological abnormalities were detected in the cochlea in Thra $^{\text {tm1/tm1 }}$ Thrb $^{\text {tm1/tm1 }}$ mice that indicated a role for TRs during the postnatal differentiation of the greater epithelial ridge of the organ of Corti (Fig. 2). During the first postnatal week, the TM, an extracellular matrix (Richardson et al., 1987), is secreted and extends from the spiral limbus across the inner sulcus to contact the hair cells in the sensory epithelium (Fig. 2A,C and see schematic diagram in Fig. $2 M$ ). The inner sulcus opens in association with the retraction of the epithelial cell layer underlying the TM. In Thra ${ }^{t m 1 / t m 1} T_{h r b^{t m 1 / t m 1}}$ pups at P8, the TM was enlarged and deformed and remained attached to the underlying epithelium; moreover, no inner sulcus was formed (Fig. 2B,D). The tunnel of Corti between the inner and outer pillar cells had not opened, and the pillar cells formed a pyramidal rise above the surface of the sensory epithelium (Fig. 2D).

In adult $\mathrm{Thra}^{\text {tm1/tm1 }} \mathrm{Thrb} \mathrm{b}^{\text {tm1/tm1 }}$ mice, the inner sulcus had opened below the TM and the sensory epithelium was differentiated (Fig. 2E-H). These results suggested that TRs are not required for the subsequent development of the greater epithelial ridge but rather that they determine the correct timing of the developmental progression. The TM however, remained permanently malformed in adults, and it was enlarged in apical and mid-turns of the cochlea (Fig. $2 F, G$ ), whereas it was often retracted in basal turns (Fig. $2 H$ ). An occasional but minimal loss of hair cells was observed in some adult but not P8 cochleas (Fig. $2 G, H)$. Systematic counts, however, showed that the hair cell loss was not statistically significant (Table 1 ). No obvious defects were observed in other regions of the cochlea.

Although TR $\beta$-deficient mice lack gross malformations in the cochlea as adults (Forrest et al., 1996), these mice showed some delay in the earlier postnatal development of the organ of Corti that represents a milder form of the phenotype present in 

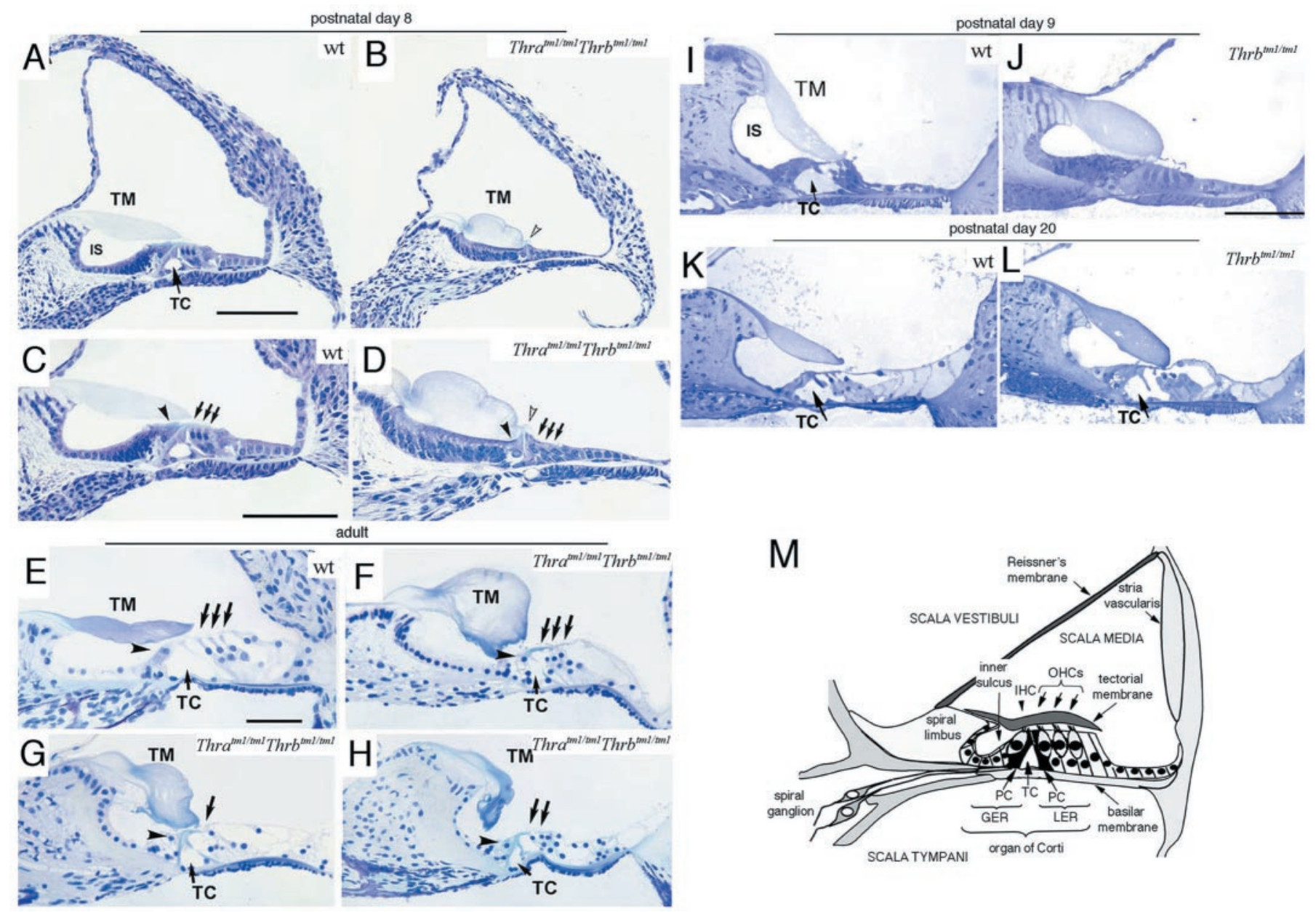

Figure 2. Cochlear malformations in $\operatorname{Thra}^{t m 1 / t m 1} \operatorname{Thrb}^{\text {tm1/tm1 }}(A-H)$ and $T h r b^{t m 1 / t m 1}(I-L)$ mouse strains. $A-H$, Thra ${ }^{\text {tm1/tm1 }}$ Thrb $^{\text {tm1/tm1 }}$ and wt control mice at postnatal day $8(A-D)$ and as adults (7- to 8-week-old) $(E-H) . A, C$, Low $(A)$ and higher $(C)$ magnification view of a mid-modiolar, midbasal turn of the cochlea from a wt pup at P8 showing the tectorial membrane (TM) extending over the inner sulcus (IS) to the hair cells (the TM is slightly retracted from the OHCs because of shrinkage during fixation). The tunnel of Corti (TC) has opened between the inner and outer pillar cells. The filled arrowhead indicates an IHC, and the three arrows indicate OHCs. Abbreviations and symbols are the same in other panels; see $M$, for full description. $B, D$, Low $(B)$ and higher $(D)$ magnification view of a midbasal turn from a Thra ${ }^{t m 1 / t m I} T h r b^{t m 1 / t m l}$ pup. The TM is enlarged, the IS has not formed, the tunnel of Corti has not opened, and the pillar cells protrude (open arrowhead) above the epithelium between the IHC and OHCs. The greater epithelial ridge below the TM is markedly thicker than in the wt pup. Scale bars: $A$ (same for $B$ ), $C$ (same for $D$ ), $100 \mu \mathrm{m}$. $E$, Apical turn of the cochlea from an adult wild-type mouse. $F, G, H$, Apical $(F)$, mid $(G)$, and basal $(H)$ turns of the cochlea of a Thra ${ }^{t m 1 / t m l} T h r b^{t m l / t m l}$ adult. The tunnel of Corti and IS have opened. An occasional but minimal loss of hair cells was evident in mid- and basal turns. The TC is present but appears somewhat misshapen. The TM is enlarged and deformed, and in basal turns is often shriveled and retracted into the IS. Scale bar: $E$ (same in $F-H$ ), $50 \mu \mathrm{m}$. $I-L$, Cochlear basal turn from Thrb ${ }^{t m l / t m l}$ and wt control mice at P9 $(I, J)$ and at P20 $(K, L)$. J, In Thrb ${ }^{t m 1 / t m 1}$ pups at P9, the formation of the IS is retarded, the TM is slightly enlarged, the underlying epithelial cell layer is thicker than in wt controls, and the tunnel of Corti (TC) is unopened. $K$, In wt mice at P20, the organ of Corti has matured (the TM in this example is slightly lifted above the OHCs because of shrinkage during fixation). $L$, In $T h r b^{t m 1 / t m 1 ~ m i c e ~ a t ~ P 20, ~ t h e ~}$ IS has opened, but the TM is slightly enlarged; the epithelium lining the IS is slightly thicker than in wt controls. The Thrb ${ }^{t m 1 / t m 1}$ phenotype is milder than in $\mathrm{Thra}^{\mathrm{tml} / \mathrm{tml} 1} \mathrm{Thrb}^{\mathrm{tml} / \mathrm{tm} 1}$ mice. I-L represent $1 \mu \mathrm{m}$ sections stained with toluidine blue (and thus differ from the $3 \mu \mathrm{m}$, thionin-stained sections in $A-H$ ). Cochleas from $n \geq 3$ mice per genotype per age were examined. $M$, Schematic diagram of major structures of the cochlea. The hair cells reside on the basilar membrane and lie below the tectorial membrane. IHC, Inner hair cell; $O H C$, outer hair cell; PC, pillar cell; TC, tunnel of Corti; GER, greater epithelial ridge; $L E R$, lesser epithelial ridge of the organ of Corti.

Thra ${ }^{t m 1 / t m 1} T^{T h b^{t m 1 / t m 1}}$ mice (Fig. 2I-L). The formation of the inner sulcus was delayed, and the tunnel of Corti remained unopened at P9 in Thrb ${ }^{t m 1 / t m 1}$ mice (Fig. 2J). The TM also showed some enlargement, although not to the extent occurring in Thra $^{\text {tm1/tm1 }}$ Thrb $^{\text {tm1/tm1 }}$ mice. In wt weanlings at P20, the organ of Corti had matured (Fig. $2 K$ ), and normal ABR thresholds could be recorded (Forrest et al., 1996). In Thrb ${ }^{t m 1 / t m 1}$ mice at P20, however, the TM was slightly enlarged, although it did extend to the hair cells and was not grossly mis-shapen as in $T h r a^{t m 1 / t m 1} T^{T h b^{t m 1 / t m 1}}$ mice. Thus, TR $\beta$ has an individual role in the timely differentiation of the organ of Corti and the correct formation of the TM. However, major control of these processes is conferred by $\operatorname{TR} \alpha 1$ and $\operatorname{TR} \beta$ acting together.

The TM also exhibited ultrastructural disarray in $\mathrm{Thra}^{\mathrm{tm} 1 / \mathrm{tm} 1}$ Thrb ${ }^{\text {tm1/tm1 }}$ mice (Fig. 3A,B). Transmission electron micrographs showed that the major collagenous fibrils were present but that the striated sheet matrix (Hasko and Richardson, 1987) was disorganized. Thus, $\operatorname{TR} \beta$ and $\operatorname{TR} \alpha 1$ jointly exert major control over both the ultrastructure and the overall form of the TM. The loss of TR $\beta$ alone resulted in a subtle form of this phenotype. Although in adult $T h r b^{\text {tm1/tm1 }}$ mice, the TM was not grossly malformed (Forrest et al., 1996), the organization of the striated 


\begin{tabular}{|c|c|c|c|}
\hline Genotype & $\begin{array}{l}\text { Inner hair cell } \\
\text { density }\end{array}$ & $\begin{array}{l}\text { Outer hair cell } \\
\text { density }\end{array}$ & $\begin{array}{l}\text { Total hair cell } \\
\text { density }\end{array}$ \\
\hline Wild type & $12.7 \pm 0.4$ & $36.3 \pm 0.8$ & $48.9 \pm 1.1$ \\
\hline Thra $^{t m 1 / t m 1} \mathrm{Thrb}^{\text {tm1/tm1 }}$ & $12.5 \pm 0.2$ & $34.3 \pm 1.0$ & $46.7 \pm 0.8$ \\
\hline
\end{tabular}

${ }^{a}$ Mean densities \pm SEM per $100 \mu \mathrm{m}$ length of the inner hair cell row in the basal-apical axis of the organ of Corti. Basal, mid-, and apical regions of the cochlea were counted, then results were pooled to determine overall averages. There was no statistically significant difference between mutant and wild-type mice (Student's $t$ test). $n=3$ mice/genotype.

Figure 3. Tectorial membrane malformation in $T h r a^{t m 1 / t m 1} T h r b^{t m 1 / t m 1}$ and

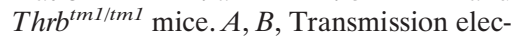
tron micrographs showing the ultrastructure of the matrix in the region of the TM that overlies the sensory hair cells in the organ of Corti in adult wt $(A)$ and Thra $^{\text {tml/tml }}$ Thrb $^{\text {tml/tml }}(B)$ mice. In wt mice, the major $20 \mathrm{~nm}$ diameter collagen fibrils (two arrowheads) are seen embedded in a striated sheet matrix formed from alternating light and dark staining, fine diameter filaments (five small arrows). In the Thra ${ }^{t m 1 / t m 1}$ Thrb ${ }^{t m 1 / t m 1}$ mouse, collagen fibrils are present, but the striated sheet matrix is disorganized throughout the TM. $C, D$, Partial disarray of TM ultrastructure in $T h r b^{t m 1 / t m 1}$ mice. The TM displays a similar disarray as Thra $^{\text {tml } 1 / t m 1}$ Thrb $^{\text {tml/tml }}$ mice in the upper region $(C)$ (i.e., those regions that are located furthest from the apical surface of the organ of Corti). The lower region $(D)$ appears normal. Micrographs shown are from a 7-month-old wt mouse $(A)$, a 6-month-old Thra ${ }^{t m 1 / t m 1} \operatorname{Thrb}^{\text {tm1/tm1 }}$ mouse $(B)$, and a 4-month-old $T h r b^{\text {tml/tml }}$ mouse $(C, D)$. Scale bar: $C$ (same in $A, B, D$ ), $200 \mathrm{~nm}$. $E$, $F$, Representative immunostaining for $\alpha$-tectorin $(E)$ and $\beta$-tectorin $(F)$ in cochlear sections of adult wt and Thra ${ }^{\text {tm1/tm1 }}$ Thrb ${ }^{t m 1 / t m 1}$ mice. In Thra ${ }^{t m 1 / t m 1}$ Thrb ${ }^{t m 1 / t m 1}$ mice, the malformation of the TM is evident, but it is still immunoreactive for the tectorins. Similar results were found for otogelin (data not shown).

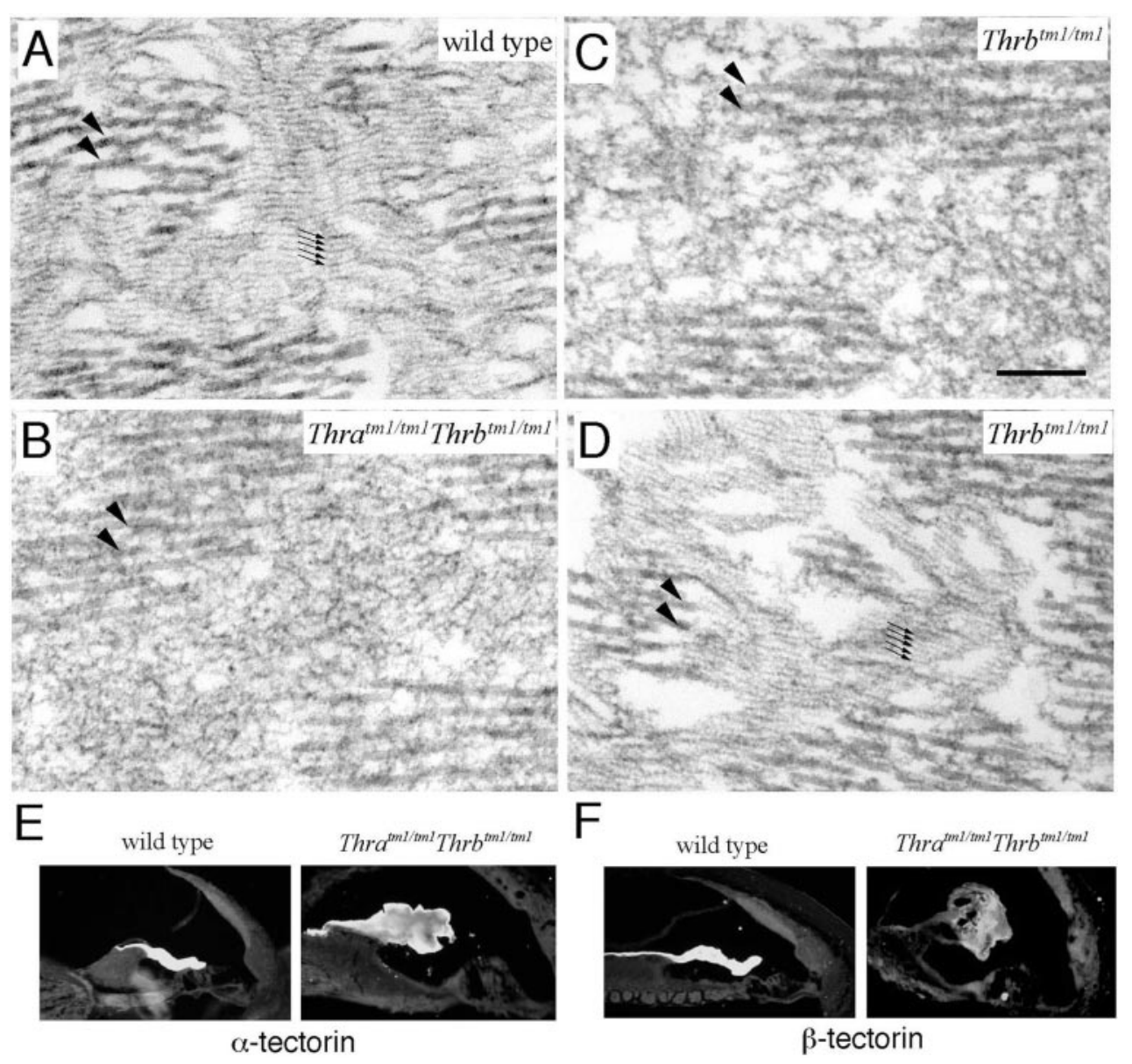

sheet matrix was disrupted in some areas. The disorganization was limited to upper regions of the TM (Fig. 3C), whereas lower regions appeared normal (Fig. 3D). Staining with antibodies against $\alpha$ - and $\beta$-tectorins (Legan et al., 2000) and otogelin (Simmler et al., 2000) in cochlear sections from Thra ${ }^{\text {tm1/tm1 }}$ $T h r b^{t m 1 / t m 1}$ mice yielded positive signals that confirmed the TM deformities but did not show any gross absence of these major components (Fig. 3E,F).

\section{Cochlear physiology in TR-deficient mice}

We investigated a role for TRs in the physiological differentiation of hair cells because mouse hair cells mature during the early postnatal period when thyroid hormone is required for the development of hearing. With the onset of auditory function at approximately P13, IHCs express the fast-activating potassium current $I_{\mathrm{K}, \mathrm{f}}$ that is associated with maturation of the IHC (Kros et al., 1998). Normally, $I_{\mathrm{K}, \mathrm{f}}$ expression begins by P13 and plateaus after P20 (Fig. 4B, wild-type curve), whereas we have shown that $I_{\mathrm{K}, \mathrm{f}}$ induction is retarded in $T h r b^{t m 1 / t m 1}$ mice (Fig. $4 B$,
Thrb ${ }^{\text {tm1/tm1 }}$ curve) (Rüsch et al., 1998). The induction of $I_{\mathrm{K}, \mathrm{f}}$ was found to be similarly retarded in $\mathrm{Thra}^{\mathrm{tm1/tm1} 1} \mathrm{Thrb}^{\mathrm{tm1/tm1}}$ mice. Figure $4 A$ shows examples of the voltage-activated currents of a control IHC from a Thra ${ }^{\text {tm1/tm1 }}$ mouse at P21, which activated rapidly to steady state levels within $2 \mathrm{msec}$ at potentials between -43 and $+1 \mathrm{mV}$, whereas the fast current was absent in a Thra ${ }^{t m 1 / t m 1} T h r b^{t m 1 / t m 1}$ mouse at P25. Analysis of IHCs $(n=13)$ from Thra ${ }^{t m 1 / t m 1} T h r b^{t m 1 / t m 1}$ mice over a range of postnatal ages showed that $I_{\mathrm{K}, \mathrm{f}}$ was eventually expressed and followed a logistic growth function that reached half-maximal expression at a time point $\left(t_{1 / 2}\right)$ of $33.6 \mathrm{~d}$ with a slope factor $s=$ 0.22/d (Fig. 4B, Thra ${ }^{t m 1 / t m 1}$ Thrb ${ }^{t m 1 / t m 1}$ curve fit), compared with the wt curve, where $t_{1 / 2}=17.5 \mathrm{~d}$ and $s=0.42 / \mathrm{d}$ (see Materials and Methods) (Rüsch et al., 1998). $I_{\mathrm{K}, \mathrm{f}}$ values of IHCs $(n=15)$ from normal-hearing $\mathrm{Thra}^{\text {tm1/tm1 }}$ or Thra ${ }^{\text {tm1/tm1 }} \mathrm{Thrb}^{+/ \mathrm{tm} 1}$ control mice closely followed the previously described developmental profile of wt mice (Kros et al., 1998; Rüsch et al., 1998) (Fig. 4B).

The similar pattern of retardation in $\mathrm{Thra}^{\mathrm{tm1/tm1}} \mathrm{Thrb}^{\mathrm{tm1/tm1}}$ 
A
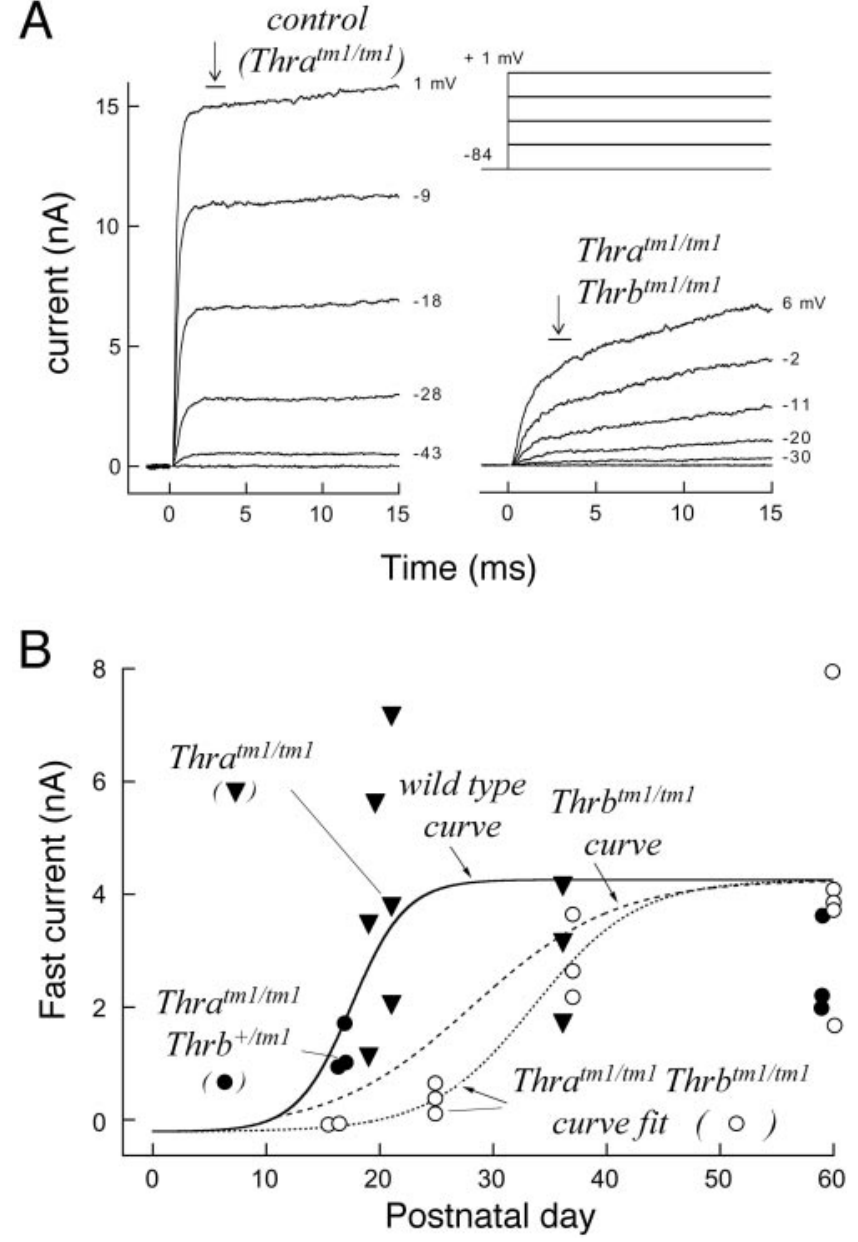

Figure 4. Delayed expression of the $I_{\mathrm{K}, \mathrm{f}}$ fast current in inner hair cells of Thra ${ }^{t m 1 / t m l} T h r b^{t m 1 / t m 1}$ mice. $A$, Fast-activating currents $\left(I_{\mathrm{K}, \mathrm{f}}\right)$ in IHCs of

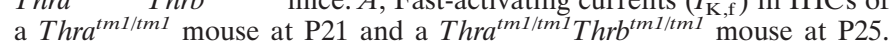
The fast component $I_{\mathrm{K}, \mathrm{f}}$ was largely missing in the $T h \mathrm{ra}^{\mathrm{tml} / \mathrm{tml} I} \mathrm{Thrb} \mathrm{b}^{\mathrm{tml} / \mathrm{tmI}}$ IHC. Arrows and bars indicate the time window during which the amplitude of $I_{\mathrm{K}, \mathrm{f}}$ was measured at $-25 \mathrm{mV}$. The voltage step protocol used is indicated above the traces of the Thra ${ }^{t m 1 / t m 1}$ Thrb ${ }^{\text {tm1/tm1 }}$ cell. B, Developmental profile of $I_{\mathrm{K}, \mathrm{f}}$ at $-25 \mathrm{mV}$ in IHCs of $\mathrm{Thra}^{\mathrm{tml} / \mathrm{tm} 1} \mathrm{Thrb} \mathrm{H}^{\mathrm{tm} 1 / \mathrm{tml} 1}$ mice. Currents were measured as indicated by the arrow and bar in $A$, and they were plotted versus the depolarizing membrane potential to obtain $I-V$ plots. $I_{\mathrm{K}, \mathrm{f}}$ was then measured at $-25 \mathrm{mV}$ from these plots by interpolating data points negative and positive to $-25 \mathrm{mV}$ and plotted versus the postnatal age of the mouse. The solid line is the previously determined curve for $I_{\mathrm{K}, \mathrm{f}}$ in IHCs of wt mice and the broken (dashed) line the curve for Thrb ${ }^{t m 1 / t m 1}$ mice as reported (Rüsch et al., 1998). The dotted line is the logistic growth function fitted to the data points plotted for IHCs of Thra ${ }^{t m 1 / t m 1} T^{2} r^{t m 1 / t m 1}$ mice (circular points), where the current maximum and minimum were fixed to the values of the wt fit [4.28 nA and $-208 \mathrm{pA}(-0.208 \mathrm{pA})] ; t_{1 / 2}=33.6 \mathrm{~d}$ and slope $=0.22 / \mathrm{d}$. Data points for $I_{\mathrm{K}, \mathrm{f}}$ from IHCs of normal-hearing Thra ${ }^{\text {tml } 1 \mathrm{tm} 1} \mathrm{Thrb}^{+/ t m 1}$ (filled circles), and Thra ${ }^{t m 1 / t m 1}$ littermates (inverted triangles) followed the normal wt developmental profile.

and in $T h r b^{t m 1 / t m 1}$ mice indicated that $I_{\mathrm{K}, \mathrm{f}}$ induction is primarily dependent on TR $\beta$. The eventual rise of $I_{\mathrm{K}, \mathrm{f}}$ in IHCs of Thra ${ }^{\text {tm1/tm1 }}$ Thrb $^{\text {tm1/tm1 }}$ mice however, shows that none of the known TRs are ultimately necessary for $I_{\mathrm{K}, \mathrm{f}}$ induction and indicates rather that TRs confer correct timing over $I_{\mathrm{K}, \mathrm{f}}$ expression during IHC maturation. IHCs of Thra ${ }^{\text {tm1/tm1 }}$ Thrb $^{\text {tm1/tm1 } 1}$ mice at stages when $I_{\mathrm{K} \text {, f }}$ was absent did develop small currents with slow kinetics that did not reach steady state during the $15 \mathrm{msec}$ time interval shown in Figure $4 A$. This type of current resembled the $I_{\mathrm{K}, \mathrm{s}}$
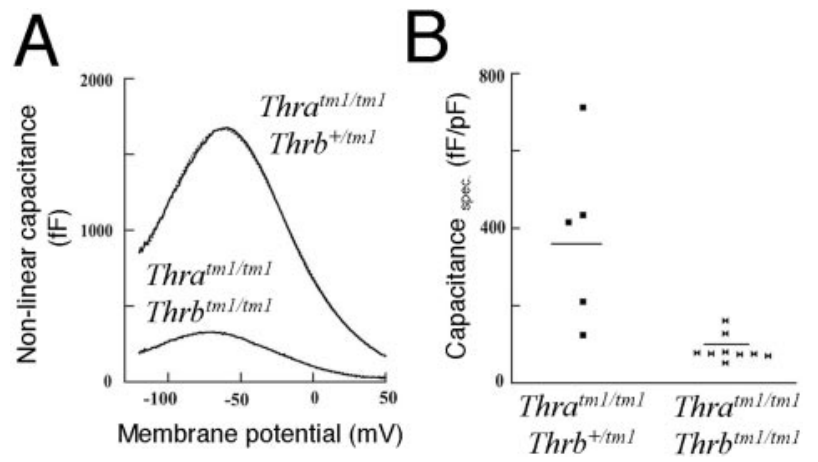

Figure 5. Reduced nonlinear capacitance in outer hair cells in $\mathrm{Thra}^{\mathrm{tm} 1 / \mathrm{tm} 1}$ $T h r b^{t m 1 / t m 1}$ mice. $A$, Measurements of nonlinear capacitance in a Thra ${ }^{\text {tm1/tm1 }}$ Thrb $^{\text {tm1/tm1 }}$ mouse and a control (Thra ${ }^{\text {tm1/tm1 }}$ Thrb $^{+/ t m 1}$ ) mouse. $B$, Plot of values of the nonlinear capacitance in five OHCs of three Thra $^{\text {tm1/tm1 }} \mathrm{Thrb}^{+/ \mathrm{tm} 1}$ control mice and in $10 \mathrm{OHCs}$ of three Thrat ${ }^{\text {tm1/tm1 }}$ $T h r b^{t m 1 / t m 1}$ mice at P8. The capacitance was significantly smaller in OHCs from Thra $^{\text {tm1/tm1 }}$ Thrb $^{\text {tm1/tm1 }}$ mice $(p<0.001)$.

slow current component described previously for IHCs of wt mice (Kros et al., 1998), suggesting that despite the lack of $I_{\mathrm{K}, \mathrm{f}}$, IHCs in Thra ${ }^{t m 1 / t m 1} T^{2} r^{t m 1 / t m 1}$ mice retained other functional properties of IHCs.

We also investigated whether TRs control the acquisition of the physiological properties of the OHCs, the second cochlear hair cell type. Most prominently, OHCs display a unique electromotility that is believed to facilitate the active amplification process of the cochlea (Holley, 1996). The underlying electromechanical transduction mechanism is based on conformational changes of a voltage-sensitive membrane motor protein, recently identified as prestin (Zheng et al., 2000). We assessed electromechanical transduction by measuring the voltage-dependent capacitance prestin imposes on the OHC membrane (Santos-Sacchi, 1991; Zheng et al., 2000) (Fig. 5). OHCs from Thra ${ }^{\text {tm1/tm1 }}$ Thrb $^{\text {tm1/tm1 }}$ pups at P8 had a significantly reduced $(p<0.001)$ nonlinear capacitance (mean $\pm \mathrm{SD} ; 87 \pm 32 \mathrm{fF} / \mathrm{pF}$ ) compared with the normal values of Thra $^{\text {tm1/tm1 }}$ Thrb $^{+/ t m 1}$ littermates $(379 \pm 228 \mathrm{fF} / \mathrm{pF})$ or the values described previously for wt pups at P8 $(290 \pm 47 \mathrm{fF} / \mathrm{pF})$ (Rüsch et al., 1998). OHCs of $T h r b^{t m 1 / t m 1}$ pups at $\mathrm{P} 8$ were previously reported to have slightly reduced nonlinear capacitance (150 \pm 46 $\mathrm{fF} / \mathrm{pF}$ ) (Rüsch et al., 1998). Thus, TRs are important for the acquisition of $\mathrm{OHC}$ electromotile properties. The slight impairment in $T h r b^{\text {tm1/tm1 }}$ pups suggests that $\operatorname{TR} \beta$ has a specific role. However, the more marked defect in Thra ${ }^{t m 1 / t m 1} T h r b^{t m 1 / t m 1}$ pups suggests that this function is largely coregulated by both $\operatorname{TR} \alpha 1$ and $\operatorname{TR} \beta$.

The potassium-rich endolymph of the scala media (see Fig. $2 M$ ) is normally maintained at a high positive resting potential that is necessary for auditory function. This endocochlear potential (EP) contributes to the driving force for mechanoelectrical transduction by the hair cells (Rübsamen and Lippe, 1997). The EP was reduced in adult $T h r a^{t m 1 / t m 1} T_{h r b}{ }^{t m 1 / t m 1}$ mice $(52.3 \pm 13.5$ $\mathrm{mV} ; p<0.001)$ compared with the normal values in Thra $^{\mathrm{tm1/tm1}}$ $T h r b^{+/ t m 1}$ mice $(100.3 \pm 9.0 \mathrm{mV})$ or the values shown previously in wt and $T h r b^{t m 1 / t m 1}$ mice (Table 2) (Steel and Barkway, 1989; Rüsch et al., 1998). The occurrence of the low EP only in Thra $^{\text {tm1/tm1 }}$ Thrb $^{\text {tm1/tm1 }}$ mice lacking all TRs suggests that the EP is normally coregulated by both $\operatorname{TR} \alpha 1$ and $\operatorname{TR} \beta$ and that these receptors are functionally interchangeable in developing the ability to generate the EP. 


\begin{tabular}{|c|c|c|c|c|}
\hline & Wild type ${ }^{a}$ & $T h r b^{t m 1 / t m 1 a}$ & Thra $^{t m 1 / t m 1} T h r b^{+/ t m 1}$ & $T h r a^{t m 1 / t m 1} T h r b^{t m 1 / t m 1}$ \\
\hline \multicolumn{5}{|l|}{ Endocochlear } \\
\hline$n=$ & 4 & 6 & 4 & $4^{b}$ \\
\hline
\end{tabular}

${ }^{a}$ Values for wild-type and Thrb ${ }^{t m 1 / t m 1}$ mice are shown for comparison and are taken from Rüsch et al. (1998).

${ }^{b} \mathrm{Thra}^{\mathrm{tml} / \mathrm{tml}} \mathrm{Thrb}^{\mathrm{tml} / \mathrm{tml} 1}$ mice were prone to die under anesthesia, and six additional mice died during attempted recording of endocochlear potentials.

* $p<0.001$ compared with Thra $^{t m 1 / t m 1}$ Thrb $^{+/ t m 1}$ or wild-type mice.

\section{Table 3. Summary of auditory system phenotypes in mice lacking TR $\alpha 1\left(T h r a^{t m 1 / t m 1}\right)$, TRß $\left(T h r b^{t m 1 / t m 1}\right)$,

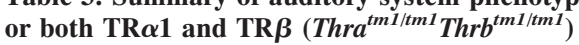

\begin{tabular}{llll} 
& \multicolumn{3}{l}{ Severity in TR-deficient mouse strains } \\
\cline { 2 - 4 } Phenotype & Thra $^{\text {tml/tml }}$ & Thrb $^{\text {tml/tml }}$ & Thra $^{\text {tml/tml Thrb }}{ }^{\text {tml/tml }}$ \\
\hline ABR impaired & - & ++ & +++ \\
Tectorial membrane deformed & $\mathrm{ND}$ & + & +++ \\
Inner sulcus, delayed differentiation & $\mathrm{ND}$ & + & ++ \\
IHC, $I_{\mathrm{K}, \mathrm{f}}$ expression retarded & - & ++ & ++ \\
OHC, nonlinear capacitance impaired & - & + & ++ \\
Endocochlear potential reduced & - & - & +
\end{tabular}

$(-)$, No phenotype detected; $(+),(++)$, or $(+++)$ indicate presence of phenotype and approximate severity $(+++$, most severe); ND, not determined; IHC, inner hair cell; OHC, outer hair cell.

\section{DISCUSSION}

The phenotype of $T h r a^{t m 1 / t m 1}{ }^{T h r} b^{t m 1 / t m 1}$ mice unmasks a role for $\operatorname{TR} \alpha 1$ that was not evident in mice lacking only $\operatorname{TR} \alpha 1$ and also indicates that $\operatorname{TR} \alpha 1$ and $\operatorname{TR} \beta$ together control novel cochlear functions. These common TR functions include a major role in the formation of the TM and in the development of the endocochlear potential and the electromechanical transduction properties of outer hair cells (Table 3 ). The masking of the full extent of these phenotypes in the single receptor gene deletions suggests a functional overlap between $\mathrm{TR} \alpha 1$ and $\mathrm{TR} \beta$ consistent with their related transactivation properties on several different DNA response elements in vitro (Jeannin et al., 1998; Wahlstrom et al., 1999). These results therefore suggest that the variety of actions provided by two related receptor genes extends the range of functions that may be controlled by thyroid hormone in cochlear development.

The unique role of $\mathrm{TR} \beta$, evident in the somewhat less severe phenotype in $T h r b^{t m 1 / t m 1}$ mice, may reflect differences in receptor expression levels in specific cochlear cell types (Bradley et al., 1994) such that inadequate levels of $\operatorname{TR} \alpha 1$ fail to substitute for the loss of $\operatorname{TR} \beta$. It is also possible that structural distinctions between $\operatorname{TR} \alpha 1$ and $\operatorname{TR} \beta$ partly constrain the ability of $\operatorname{TR} \alpha 1$ to regulate a critical subset of $\operatorname{TR} \beta$ target genes in the cochlea. TR $\alpha 1$ and TR $\beta$ diverge completely in the $\mathrm{N}$ terminus, which plays a role in DNA binding stability and in the transactivation properties of the receptor. They also have certain differences in their central DNA binding domains which contribute to functional differences on some response elements in vitro (Lezoualc'h et al., 1992; Sjöberg and Vennström, 1995; Zhu et al., 1997). The identification of the direct, downstream target genes that mediate the physiological actions of TRs in the cochlea may allow the elucidation of the basis of this TR isotype-specificity.

The cochlear abnormalities in $T h r a^{t m 1 / t m 1} T h r b^{t m 1 / t m 1}$ mice that lack all known TRs resemble the defects described in hypothyroid mice or rats, which suggests that $\operatorname{TR} \alpha 1$ and $\operatorname{TR} \beta$ together account for the known functions of thyroid hormone in the cochlea. The induction of hypothyroidism in mice and rats during a critical, early window beginning at or before the time of birth (Deol, 1973; Uziel et al., 1981; Uziel, 1986) causes a similar retardation in the formation of the inner sulcus and deformity of the TM as is found in $T h r a^{t m 1 / t m 1} T h r b^{t m 1 / t m 1}$ mice. Our findings thus argue against the hypothetical existence of any other unknown TRs or non-TR-mediated mechanism of action of thyroid hormone in cochlear development. A range of cloning and functional studies suggest that $\operatorname{TR} \alpha 1$ and $\operatorname{TR} \beta$ represent the full complement of nuclear TRs (Gauthier et al., 1999; Göthe et al., 1999). However, the growth retardation and other phenotypes of Thra ${ }^{\text {tm1/tm1 }}$ Thrb $^{\text {tm1/tm1 }}$ mice are somewhat milder than the phenotypes of severe hypothyroidism, a distinction that has raised the possibility of non-TR pathways of action of thyroid hormone or of hormone-independent actions of TRs in some systems (Göthe et al., 1999). The similar cochlear phenotypes of hormone- or TR-deficient mice, however, make it unlikely that such mechanisms need be invoked in the cochlea. Although current evidence allows us to draw a conclusion regarding cochlear morphology, these comparisons cannot be extended to the physiological defects we report for $T h r a^{t m 1 / t m 1} T h r b^{t m 1 / t m 1}$ mice, because cochlear physiology has been little studied in hypothyroid rodents.

The malformation of the TM in Thra $^{\text {tm1/tm1 }}$ Thrb $^{\text {tm1/tm1 }}$ mice would impair hair cell mechanosensitive transduction and the tuning of basilar membrane motion, as indicated by other mutations in TM structural components. The complete detachment of the $\mathrm{TM}$ in $\operatorname{Tecta}^{\triangle E N T / \triangle E N T}$ mice with a large deletion in the entactin-like domain of $\alpha$-tectorin reduces the sensitivity of basilar membrane motion by $35 \mathrm{~dB}$ (Legan et al., 2000). Also, human $\alpha$-tectorin mutations cause deafness (Verhoeven et al., 1998) and deletions of type XI collagen $\alpha 2$ (McGuirt et al., 1999), and otogelin (Simmler et al., 2000) cause TM abnormalities and impair the ABR. The integrity of the compart- 
ments formed by the TM, the inner sulcus, and adjacent interdental cells of the spiral limbus may also be critical for auditory function and may contribute to the control of the ionic microenvironement and the potassium recycling that are necessary for hair cell function (Spicer and Schulte, 1998; Steel and Kros, 2001; Ulfendahl et al., 2001). Because the roles of the inner sulcus and its functional relationship to the TM and hair cells are incompletely understood at present, it is possible that other, as yet unknown functions are disrupted by the loss of TRs.

The TM in $T h r a^{t m 1 / t m 1}$ Thrb ${ }^{t m 1 / t m 1}$ mice possesses collagen fibrils and is immunoreactive for tectorins and otogelin, suggesting that TRs are not required for expression of these major TM components. A more subtle role for TRs could be in the control of the correct amount and timing of expression of TM components by the greater epithelial ridge (Rau et al., 1999), which could explain the enlargement of the TM in Thra ${ }^{\text {tm1/tm1 }}$ $T h r b^{t m 1 / t m 1}$ mice. The dysregulated secretion of the TM could also be secondary to the more general delay in the reshaping of the greater epithelial ridge during the delayed differentiation of the inner sulcus. The ultrastructural disarray of the TM in both Thrb ${ }^{\text {tm1/tm1 }}$ and Thra ${ }^{\text {tm1/tm1 }}$ Thrb $^{\text {tm1/tm1 }}$ mice (Fig. 3) suggests another subtle role, which is at least partly $\operatorname{TR} \beta$-specific, in the formation of the striated sheet matrix of the TM. This could involve, for example, glycosylation or other forms of processing of TM components (Richardson et al., 1987).

This study identifies roles for TRs in the physiological differentiation of both IHCs and OHCs. Immature IHCs and OHCs resemble each other morphologically (Pujol et al., 1997) and functionally (Kros, 1996) before they differentiate into mature hair cell types with distinct properties. In rodent postnatal development, OHCs have been suggested to enter a second phase of differentiation during which they acquire their unique properties including electromotility (Pujol et al., 1997). Although TRs are not required for the commitment to form either IHCs or $\mathrm{OHCs}$, they are required subsequently for the proper maturation of both hair cell types. The defect in $\mathrm{OHC}$ nonlinear capacitance in $\mathrm{Thra}^{\mathrm{tm1/tm1}} \mathrm{Thrb}^{\mathrm{tm1/tm1}}$ mice is in accord with the altered distortion product otoacoustic emissions, a measure of OHC activity, reported in the hyt/hyt hypothyroid mouse strain (Li et al., 1999). It remains to be determined whether the defects in hair cell maturation are because of the absence of TRs within the hair cells or are indirect, perhaps because of abnormalities in maturation factors or in cell-cell interactions that are normally directed by other regions of the organ of Corti.

The stria vascularis has a major role in generating the endocochlear potential in the scala media of the cochlea (Fig. 2M), and defects in its function could contribute to the reduced endocochlear potential in Thra $^{\text {tm1/tm1 }} \mathrm{Thrb}^{\text {tm1/tm1 }}$ mice. This may be consistent with the suggested regulation of NaK-ATPases in the stria vascularis by thyroid hormone (Zuo and Rarey, 1996). It is also possible that this defect originates elsewhere in the cochlea, for example in cells of the spiral limbus that may be involved in potassium recycling (Spicer and Schulte, 1998; Steel and Kros, 2001). The IHC and OHC defects together with the abnormal TM and low endocochlear potential could explain the profound abrogation of auditory function found in $\mathrm{Thra}^{\mathrm{tm1/tm1}} \mathrm{Thr} \mathrm{b}^{\mathrm{tm1/tm1}}$ mice, as indicated by the severely defective ABR. This need not exclude additional roles for TRs in more central auditory pathways, as is suggested in hypothyroid rodents that show changes in innervation and myelination of the cochlear nerve (Uziel, 1986; Knipper et al., 1998), in expression of type 2 deiodinase in brainstem cochlear nuclei (Guadaño-Ferraz et al., 1999) and in pyramidal cell morphology in the auditory cortex (Ruiz-Marcos et al., 1983).

Several features of the cochlear phenotype, including the retarded development of the inner sulcus and IHC $I_{\mathrm{K}, \mathrm{f}}$ current reflect delays rather than permanent defects. Thus, other signals or transcriptional pathways (Corey and Breakefield, 1994) must set the ultimate developmental course for these events, whereas TRs confer correct timing. Conceivably, the maturation of auditory function may require activity and sensory inflow during critical periods (Rübsamen and Lippe, 1997; Rüsch et al., 1998), perhaps resembling other sensory systems, such as vision (Katz and Shatz, 1996). As ligand-dependent transcription factors, TRs are well adapted to such a role because they can alter the cochlear transcriptional program in response to temporal signals provided by rising thyroid hormone levels in development (Campos-Barros et al., 2000). Thyroid hormone also has a timing role in amphibian metamorphosis (Huang et al., 2001), suggesting that an interplay between rising hormone levels and specific TRs in target tissues provides a timing control that can be adapted to very different processes in vertebrate development.

\section{REFERENCES}

Bradley DJ, Towle HC, Young III, WS (1994) $\alpha$ and $\beta$ thyroid hormone receptor (TR) gene expression during auditory neurogenesis: evidence for TR isoform-specific transcriptional regulation in vivo. Proc Natl Acad Sci USA 91:439-443.

Brucker-Davis F, Skarulis MC, Pikus A, Ishizawar D, Mastroianni M-A, Koby M, Weintraub BD (1996) Prevalence and mechanisms of hearing loss in patients with resistance to thyroid hormone (RTH). J Clin Endocrinol Metab 81:2768-2772.

Campos-Barros A, Amma LL, Faris JS, Shailam R, Kelley MW, Forrest D (2000) Type 2 iodothyronine deiodinase expression in the cochlea before the onset of hearing. Proc Natl Acad Sci USA 97:1287-1292.

Corey DP, Breakefield XO (1994) Transcription factors in inner ear development. Proc Natl Acad Sci USA 91:433-436.

Dallos P, Popper A, Fay R (1996) The cochlea. New York: Springer.

Deol MS (1973) An experimental approach to the understanding and treatment of hereditary syndromes with congenital deafness and hypothyroidism. J Med Genetics 10:235-242.

Deol MS (1976) The role of thyroxine in the differentiation of the organ of Corti. Acta Otolaryngol 81:429-435.

Forrest D, Erway LC, Ng L, Altschuler R, Curran T (1996) Thyroid hormone receptor $\beta$ is essential for development of auditory function. Nat Genet 13:354-357.

Gauthier K, Chassande O, Plateroti M, Roux J-P, Legrand C, Pain B, Rousset B, Weiss R, Trouillas J, Samarut J (1999) Different functions for the thyroid hormone receptors $\operatorname{TR} \alpha$ and $\operatorname{TR} \beta$ in the control of thyroid hormone production and post-natal survival. EMBO J 18:623-631.

Göthe, S, Wang, Z, Ng, L, Nilsson, J, Campos-Barros, A, Ohlsson, C, Vennström, B, Forrest D (1999) Mice devoid of all known thyroid hormone receptors are viable but exhibit disorders of the pituitarythyroid axis, growth and bone maturation. Genes Dev 13:1329-1341.

Guadaño-Ferraz, A, Escámez, M, Rausell, E, Bernal J (1999) Expression of type 2 iodothyronine deiodinase in hypothyroid rat brain indicates an important role of thyroid hormone in the development of specific primary sensory neurons. J Neurosci 19:3430-3439.

Hasko J, Richardson GP (1987) The ultrastructural organization and properties of the mouse tectorial membrane matrix. Hear Res 35:21-38.

Hébert R, Langlois J-M, Dussault JH (1985) Permanent defects in rat peripheral auditory function following perinatal hypothyroidism: determination of a critical period. Dev Brain Res 23:161-170.

Holley M (1996) Outer hair cell motility. In: The cochlea (Dallos P, Popper A, and Fay R, eds), pp 386-434. New York: Springer.

Huang H, Cai L, Remo BF, Brown DD (2001) Timing of metamorphosis and the onset of the negative feedback loop between the thyroid gland and the pituitary is controlled by type II iodothyronine deiodinase in Xenopus laevis. Proc Natl Acad Sci USA 98:7348-7353.

Jeannin E, Robyr D, Desvergne B (1998) Transcriptional regulatory patterns of the myelin basic protein and malic enzyme genes by the thyroid hormone receptors $\alpha 1$ and $\beta 1$. J Biol Chem 273:24239-24248

Katz L, Shatz C (1996) Synaptic activity and the construction of cortical circuits. Science 274:1133-1138.

Knipper M, Bandtlow C, Gestwa L, Kopschall I, Rohbock K, Wiechers B, Zenner H-P, Zimmermann U (1998) Thyroid hormone affects 
Schwann cell and oligodendrocyte gene expression at the glial transition zone of the VIIIth nerve prior to cochlea function. Development 125:3709-3718.

Kros C (1996) Physiology of mammalian cochlear hair cells. In: The cochlea (Dallos P, Popper A, and Fay R, eds), pp 318-385. New York: Springer.

Kros C, Ruppersberg J, Rüsch A (1998) Expression of a potassium conductance in inner hair cells at the onset of hearing in mice. Nature 394:281-284.

Lauterman, J, ten Cate, W-JF (1997) Postnatal expression of the $\alpha$-thyroid hormone receptor in the rat cochlea. Hear Res 107:23-28.

Legan PK, Lukashkina VA, Goodyear RJ, Kössl M, Russell IJ, Richardson GP (2000) A targeted deletion in alpha-tectorin reveals that the tectorial membrane is required for the gain and timing of cochlear feedback. Neuron 28:273-285.

Lezoualc'h, F, Hassan AHS, Giraud, P, Loeffler, J-P, Lee SL, Demeneix BA (1992) Assignment of the $\beta$-thyroid hormone receptor to $3,5,3^{\prime}-$ triiodothyronine-dependent inhibition of transcription from the thyrotropin-releasing hormone promoter in chick hypothalamic neurons. Mol Endocrinol 6:1797-1804.

Li D, Henley CM, O’Malley Jr BW (1999) Distortion product otoacoustic emissions and outer hair cell defects in the hyt/hyt mutant mouse. Hear Res 138:65-72.

McGuirt WT, Prasad SD, Griffith AJ, Kunst HP, Green GE, Shpargel KB, Runge, C, Huybrechts, C, Mueller RF, Lynch, E, King MC, Brunner HG, Cremers CW, Takanosu M, Li SW, Arita M, Mayne R, Prockop DJ, Van Camp G, Smith RJ (1999) Mutations in COL11A2 cause non-syndromic hearing loss (DFNA13). Nat Genet 23:413-419.

Morreale de Escobar G, Pedraza P, Escobar del Rey F, Obregón M (1996) Thyroidal and extrathyroidal adaptation to graded doses of iodine deficiency: an experimental model for the study of neurological iodine deficiency disorders (IDD). In: Thyroid and Trace Elements (Braverman L, Köhrle J, Eber O, and Langsteger W, eds), pp 113-126. Vienna: Blackwell Scientific.

O'Malley BW, Li D, Turner DS (1995) Hearing loss and cochlear abnormalities in the congenital hypothyroid (hyt/hyt) mouse. Hear Res 88:181-189.

Oliver D, Fakler B (1999) Expression density and functional characteristics of the outer hair cell motor protein are regulated during postnatal development in rat. J Physiol (Lond) 519:791-800.

Platzer J, Engel J, Schrott-Fischer A, Stephan K, Bova S, Chen H, Zheng H, Striessnig J (2000) Congenital deafness and sinoatrial node dysfunction in mice lacking class D L-type $\mathrm{Ca}^{2+}$ channels. Cell 102:89-97.

Pujol R, Lavigne-Rebillard M, Lenoir M (1997) Development of sensory and neural structures in the mammalian cochlea. In: Development of the auditory system (Rubel E, Popper A, and Fay R, eds), pp 146-192. New York: Springer.

Rau A, Legan PK, Richardson GP (1999) Tectorin mRNA expression is spatially and temporally restricted during mouse inner ear development. J Comp Neurol 405:271-280.

Refetoff S, DeWind LT, DeGroot LJ (1967) Familial syndrome combining deaf-mutism, stippled epiphyses, goiter, and abnormally high PBI: possible target organ refractoriness to thyroid hormone. J Clin Endocrinol Metab 27:279-294.

Richardson GP, Russell IJ, Duance VC, Bailey AJ (1987) Polypeptide composition of the mammalian tectorial membrane. Hear Res 25:45-60.

Rübsamen R, Lippe WR (1997) The development of cochlear function. In: Development of the auditory system (Rubel EW, Popper AN, and Fay RR, eds), pp 193-270. New York: Springer.

Ruiz-Marcos A, Salas J, Sanchez-Toscano F, Escobar Del Rey F, Morreale de Escobar G (1983) Effect of neonatal and adult-onset hypothyroidism on pyramidal cells of the rat auditory cortex. Dev Brain Res 9:205-213.

Rüsch A, Erway L, Oliver D, Vennström B, Forrest D (1998) Thyroid hormone receptor $\beta$-dependent expression of a potassium conductance in inner hair cells at the onset of hearing. Proc Natl Acad Sci USA 95:15758-15762.

Santos-Sacchi J (1991) Reversible inhibition of voltage-dependent outer hair cell motility and capacitance. J Neurosci 11:3096-3110.

Sap J, Muñoz A, Damm K, Goldberg Y, Ghysdael J, Leutz A, Beug H, Vennström B (1986) The c-erbA protein is a high affinity receptor for thyroid hormone. Nature 324:635-640.

Simmler MC, Cohen-Salmon M, El-Amraoui A, Guillaud L, Benichou JC, Petit C, Panthier JJ (2000) Targeted disruption of otog results in deafness and severe imbalance. Nat Genet 24:139-143.

Sjöberg M, Vennström B (1995) Ligand-dependent and -independent transactivation by thyroid hormone receptor $\beta 2$ is determined by the structure of the hormone response element. Mol Cell Biol 15:4718-4726.

Spicer SS, Schulte BA (1998) Evidence for a medial K+ recycling pathway from inner hair cells. Hear Res 118:1-12.

Steel KP, Barkway C (1989) Another role for melanocytes: their importance for normal stria vascularis development in the mammalian inner ear. Development 107:453-463.

Steel KP, Kros CJ (2001) A genetic approach to understanding auditory function. Nat Genet 27:143-149.

Trotter W (1960) The association of deafness with thyroid dysfunction. Br Med Bull 16:92-98.

Ulfendahl M, Flock A, Scarfone E (2001) Structural relationships of the unfixed tectorial membrane. Hear Res 151:41-47.

Uziel A (1986) Periods of sensitivity to thyroid hormone during the development of the organ of Corti. Acta Otolaryngol (Stockh) 429:23-27.

Uziel A, Gabrion J, Ohresser M, Legrand C (1981) Effects of hypothyroidism on the structural development of the organ of Corti in the rat. Acta Otolaryngol 92:469-480.

Van Middlesworth L, Norris C (1980) Audiogenic seizures and cochlear damage in rats after perinatal antithyroid treatment. Endocrinology 106:1686-1690.

Verhoeven K, Van Laer L, Kirschhofer K, Legan PK, Hughes DC, Schatteman I, Verstreken M, Van Hauwe P, Coucke P, Chen A, Smith RJ, Somers T, Offeciers FE, Van de Heyning P, Richardson GP, Wachtler F, Kimberling WJ, Willems PJ, Govaerts PJ, Van Camp G (1998) Mutations in the human alpha-tectorin gene cause autosomal dominant non-syndromic hearing impairment. Nat Genet 19:60-62.

Wahlstrom GM, Vennstrom B, Bolin MB (1999) The adenovirus E1A protein is a potent coactivator for thyroid hormone receptors. Mol Endocrinol 13:1119-1129.

Weinberger C, Thompson CC, Ong ES, Lebo R, Gruol DJ, Evans RM (1986) The $c$-erb-A gene encodes a thyroid hormone receptor. Nature 324:641-646.

Wikström L, Johansson C, Saltó C, Barlow C, Campos Barros A, Baas F Forrest D, Thorén P, Vennström B (1998) Abnormal heart rate and body temperature in mice lacking thyroid hormone receptor $\alpha 1$. EMBO J 17:455-461.

Zheng J, Shen W, He DZ, Long KB, Madison LD, Dallos P (2000) Prestin is the motor protein of cochlear outer hair cells. Nature 405:149-155.

Zheng QY, Johnson KR, Erway LC (1999) Assessment of hearing in 80 inbred strains of mice by ABR threshold analyses. Hear Res 130:94-107.

Zhu X-G, McPhie P, Lin K-H, Cheng S-Y (1997) The differential hormone-dependent transcriptional activation of thyroid hormone receptor isoforms is mediated by interplay of their domains. J Biol Chem 272:9048-9054.

Zuo J, Rarey K (1996) Responsiveness of $\alpha 1$ and $\beta 1$ cochlear $\mathrm{Na}$, K-ATPase isoforms to thyroid hormone. Acta Otolaryngol (Stockh) 116:422-428. 